SHIRLEY CHAN

\title{
INTRODUCTION: \\ DISCOVERING AND REDISCOVERING THE FOUR BOOKS
}

The adoption of Confucianism as the state orthodoxy in the Han Dynasty (206 BCE-CE 220) and the revival of Confucianism in the Song Dynasty (960-1279) means that the influence of the Confucian Classics has been repeatedly reinforced in Chinese philosophy and history.

Given their canonical status, the impulse to reflect upon and the attempt to comprehend the "Four Books" have persisted since then with keen interest. These four books-the Great Learning (the Daxue 《大學》), the Analects (the Lunyu 《論語》), the Works of Mencius (the Mengzi 《孟子》), and the Doctrine of the Mean (the Zhongyong 《中庸》) - have been interpreted and reinterpreted by Chinese scholars as establishing the basic teachings and core values of the Confucian tradition, resulting in a plethora of commentaries and sub-commentaries over the centuries. Today, scholars in China and abroad continue their journeys of discovery and rediscovery of the Confucian canon with an ever-expanding horizon that encompasses the fields of hermeneutics, textual interpretation, and comparative studies, as they attempt to illuminate these words of wisdom.

The International Symposium on the Confucian Four Books (Guoji Sishu Xueshu Yantaohui 國際四書學術研討會) was held at Renmin University, Beijing, on April 28-29, 2013, under the joint auspices of the Institute of the Chinese Classics, Renmin University, and the International Society of Chinese Philosophy. Some forty papers were presented by scholars from mainland China, Taiwan, the United Kingdom, Hong Kong, Korea, America, and Australia. This special issue is a collection of selected papers from and outside the symposium with discussions focusing on the Four Books and witnesses yet another intellectual enterprise to come to grips with the words and thoughts of the ancient masters and sages. The articles gathered here, though mostly focused on the Confucian Analects with two on the Four Books in general, provide an opportunity for exploring several interpretive intersections, encounters, and divergences between traditional and

SHIRLEY CHAN, Senior Lecturer and Head of Chinese Studies, Department of International Studies, Macquarie University. Specialties: textual studies, Chinese philosophy, intellectual history. E-mail: shirley.chan@mq.edu.au

Journal of Chinese Philosophy 40:2 (June 2013) 224-233

(C) 2013 Journal of Chinese Philosophy 
modern as well as Chinese and Western hermeneutics on the Four Books. Taken as a whole, these contributions directly and indirectly raise anew questions of how to interpret the Confucian Classics.

While some eminent thinkers in Europe have been pondering the subject of hermeneutics over the past two centuries, "Chinese hermeneutics" did not emerge as a distinctive field of study in China and East Asia until the 1980s. ${ }^{1}$ Hermeneutics owes its origins to the exegetical principles for interpreting the Bible, but has later developed into a general interpretive theory for both scriptural and secular texts. ${ }^{2}$ German philologist Friedrich Ast (1778-1841) asserts that the aim of philological studies is to grasp the "spirit" of antiquity that finds expression in "the literary heritage," which, in turn, is transmitted through words structured by grammar. ${ }^{3}$ This approach, generally known as scriptural or heuristic hermeneutics, holds the view that a text is "a repository of authoritative norms for the culture" and that a good interpretation of a text makes those timeless truths meaningful to a modern reader. ${ }^{4}$

The alternative approach-historical hermeneutics-claims that textual meaning is perceived through human experience. As an alternative approach, historical hermeneutics attempts to go behind the linguistic veneer, with a view to uncovering the innermost dynamic of the text (i.e., the subtext). This involves both intrinsic and extrinsic studies such as close reading of the text (for which scriptural hermeneutics is a convenient starting point), investigation into the mode of textual formation and transmission, the author and authorial intent (in this case how words and deeds were attributed to the master and/or his disciples whose words and deeds were recorded), and above all the historicity of the discourses. German philosopher Friedrich Schleiermacher (1768-1834) affirms that reconstructing the historical context is basic to the understanding of any ancient text. ${ }^{5}$ Likewise inspired, Wilhelm Dilthey (1833-1911) claims that the aim of humanity studies is "to 'understand' meaningful human expressions by putting them into their concrete social and historical contexts." Martin Heidegger (1889-1976) asserts that in interpreting a text, understanding does not arise from an empty consciousness but a "prestructured" understanding in which "ideational preconceptions" establish ways of seeing and interpreting. ${ }^{7}$ In other words, as understanding is the basis for all interpretation, it must be made within a horizon of "already granted meanings and intentions" that meets the horizon of the text as it reveals itself. To Heidegger, hermeneutics is to bring out the "unsaid" or hidden meaning of a text by going behind it and "ask what the author did not and could not say, yet which in the text comes to light as its innermost dynamic." Thus interpretation is to discern the "inner violence and struggle which were at work in the 


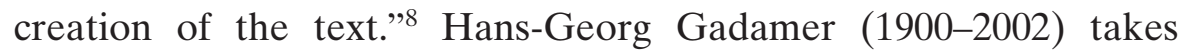
Schleiermacher's temporal dimension a step further, as he considers the true task of hermeneutics to be to integrate history with the present, and not merely to restore the past. ${ }^{9}$ In any case, a good interpretation is, according to historical hermeneutics, an understanding which approximates that of the author, audience, and context. ${ }^{10}$

Chinese "hermeneutics"-I use quotation marks here for the obvious reasons - is dominated by textual commentaries and exegesis boasting a long tradition. Instead of being a distinctive academic discipline as it is in the West, the sporadic conceptualization of Chinese "hermeneutics" appears as obiter dicta alongside various philosophical and exegetical discourses. ${ }^{11}$ In fact Chinese scholars have been interpreting and reinterpreting ancient texts for over two thousand years without claiming their praxis in the name of hermeneutics, which, until recently, has not been pursued as an architectonic end in itself. Modern Chinese hermeneutists have traced their long tradition back to the Book of Mencius in which two interpretive principles, hailed as having seminal importance, can be deduced. ${ }^{12}$ First:

\section{故説詩者, 不以文害辭, 不以辭害志。以意逆志, 是為得之。}

Hence in explaining an ode, one should not allow the words to get in the way of the sentence, nor the sentence to get in the way of the sense. The right way is to meet the intention of the poet with sympathetic understanding. ${ }^{13}$

The hermeneutic principle that can be extrapolated from the above passage is “yiyi nizhi 以意逆志 (meeting the intent of the author with sympathetic understanding)." Different scholars have tried to explain this concept in practical terms: Zhao Qi's 趙岐 (?-210 CE) takes it to mean that interpretation is to seek the intent of the poet or author. ${ }^{14}$ Nishijima Lankei 西島蘭溪 (1780-1852) adds that authorial intent should be actively sought by "tracing thoughts through hundreds of generations." ${ }^{15} \mathrm{Zhu} \mathrm{Xi}$ 朱喜 (1130-1200) asserts that the interpreter should not subjectively impose meaning onto the text but wait patiently for the author's intent to reveal itself. ${ }^{16}$ From an etymological point of view the word $n i$ 逆 means to meet, anticipate, or encounter a person or thing in the other direction. The above scholarly opinions seem to concur that $y i$ 意 in yiyi nizhi refers to the interpreter's understanding or thought whereas $z h i$ 志 refers to the author's intent. Thus Mencius's concept of the interpreter's yi can be compared with Heidegger's "ideational preconceptions" or the horizon of the interpreter, but the point of departure is that instead of "meeting" ( $n i$ in Mencius's words) authorial intent (zhi), it is the horizon of the text that the interpreter meets. 
Second, Mencius says,

頌其詩, 讀其書, 不知其人, 可乎? 是以論其世也。是尚友也。

When one reads the poems and writings of the ancients, can it be right not to know something about them as men? Hence one tries to understand the age in which they lived. This can be described as looking for friends in history. ${ }^{17}$

Though the tenor of the above discourse is about "shangyou guren 尚友古人 (befriending the ancients)," by extrapolation the idea of “zhiren lunshi 知人論世 (knowing the authors and the age they lived in)" has become a frequently quoted axiom for textual interpretation. The hermeneutic purport of knowing the authors and their times runs across the grain of Heidegger's and Gadamer's hermeneutics that seeks to understand the text not the author. ${ }^{18}$

The Western literary movement of New Critics declares that authorial intent is "neither available nor desirable" as meaning resides within the text and is not to be found in biographies. ${ }^{19}$ By proclaiming the death of the author Structuralist (more often referred to as Post-structuralist) Roland Barthes has endorsed readers with the right to decode meaning from a text, as the author is no longer in control of it once it has entered the public domain. ${ }^{20}$ Much earlier Wang Fuzhi 王夫之 (1619-1692) has asserted that although an author may tend toward a singular meaning, readers may derive from it their own different interpretations. ${ }^{21} \mathrm{~A}$ closer examination of the axiom yiyi nizhi may suggest that it is not categorically referring to authorial intent; $z h i$ could be the intent or the general scope of the text, as James Legge's translation has suggested. ${ }^{22}$ This reading aligns $z h i$ with Heidegger's conception of textual horizon as previously discussed. By focusing on the text, intelligibility is a function of language and therefore interpretation becomes dialogical. Russian philosopher and linguist Mikhail Bakhtin asserts that meaning is to be found in the dialogic exchanges of language between the speaker and listener (or author and reader). It is therefore necessary to focus on language (or text which is language recorded in signs), because in reality whatever approach it takes to interpret texts, language is the medium for perception. Almost invariably the authors and the age in which they lived are inscribed in text. Thus, in order to meet the horizon of the text the interpreter is to let the text speak. As Montrose aptly asserts, "the social is understood to be discursively constructed"; and "language-use is understood to be always and necessarily dialogical, to be socially and materially determined and constrained." 23

As a transmitter rather than an innovator by his own admission, ${ }^{24}$ Confucius has not authored any books but his ideological legacy has 
been preserved in the Lunyu (or the Confucian Analects). The extant corpus - a collection of aphorisms, dialogues, and anecdotes - is the product of multiple authorship and repetitive editorial endeavors. Its anachronically arranged chapters and passages ${ }^{25}$ whose rhetoric is terse and barely contextualized, evince textual simplicity that belies ideological complexity. It is from these fragmentary, incoherent, and sometimes duplicative discourses that the macrocosm of Confucius's thoughts has been constructed. Traditionally, the Analects has been studied through the lens of scriptural hermeneutics whereby cultural and philosophical values have been extrapolated and identified as universal truths without much reference to the historical setting of the text. Despite persistent interpretation and reinterpretation, these scriptural commentaries are often vague and elliptical. ${ }^{26}$ As the historical contexts of the Analects are temporally and socially specific, the recourse to historicism as a means of interpretation raises the question of the universality of Confucian ethics. However, scriptural and historical hermeneutics are neither mutually exclusive methodologies nor binary opposites for decoding meaning. There are no compelling reasons to polarize the etymological/linguistic and the historical/social. In this regard Shu-hsien Liu's view is particularly illuminating on a practical level:

\begin{abstract}
Although moral principles are absolute and universally applicable, moral maxims are only relative and confined to particular situations. ... There is no longer an emperor to be loyal to; and the expectations between father and son, man and wife, brother and brother, and friend and friend have changed in a most radical way. ... A study of Confucian ethics does not seem to have any relevance for the ethical attitude of a modern man. ... To look at the problem from such a point of view, however, is to pay attention only to the letter but not to the spirit of Confucian moral philosophy. ${ }^{27}$
\end{abstract}

By differentiating "moral principles" from "moral maxims," Liu in effect implies that the act of interpretation yields different layers of meaning. As "moral maxims" are "relative and confined to particular situations" they are intelligible through historic hermeneutics. "Moral principles", on the other hand, are the trans-historical and trans-cultural values of Confucius's teachings that could be deduced with or without reference to their historical contexts. At the same time, while "some of these cultural values can be elucidated by purely philosophical means ... [h]istorical studies provide some of the conditions for a deeper understanding of the ideology that arose from a particular historical situation." 28 It is fair to conclude that historical hermeneutics is an existential process of interpretation through historical and socially construed language, both oral and written. 
In this issue, articles written by Berhard Fuehrer and Lauren Pfister describe cases of how the Confucian Analects has been subject to various interpretations either as teaching materials or as a canonical text by Confucian scholars in its textual transmission and commentarial tradition in different periods of Chinese history. In his "Orality and the Transmission of Interpretations in Two Versions of Huang Kan's Lunyu Yishu," Bernhard Fuehrer explores the received version of Huang Kan's 皇㑆 (488-545) Lunyu Yishu and a Tang manuscript fragment that derives from it, with a view to investigating residues of the oral transmission of glosses and interpretations of the Analects. The discussion is based on close readings of the passages that display remnants of the oral transmission of interpretations and attest to pedagogical techniques applied by Huang Kan in his classroom in the Liang Period (502-557) and by an unknown tutor in Dunhuang toward the end of the Tang Dynasty (618-907). The two versions of the Lunyu Yishu are read as texts of oral utterances bearing evidence of two distinct layers of recognizable oral vestiges.

On the other hand in his article "Mao Qiling's Critical Reflections on the Four Books" Lauren Pfister elucidates how the Qing scholar challenges Cheng-Zhu's textual interpretations of the Four Books and offers an alternative account of the sagely way by following Wang Yangming's interpretation. Pfister's article will enable us, through Mao's approach, to ask further philosophical questions related to the canonization and controversies surrounding the character and significance of the Four Books for Ruist traditions during the Qing Dynasty.

\section{Approaches to the $A$ nalects}

Studies of the Analects and the Four Books by modern scholars have approached it from a wide range of perspectives emphasizing its cultural values. Some scholars analyze its educational, social, and political topoi ${ }^{29}$ or translate the text and critique its textual coherence, ${ }^{30}$ others explicate its philosophical themes of ren 仁 (benevolence), $y i$ 義 (righteousness), and $l i$ 禮 (propriety), ${ }^{31}$ or such didactic "visions" as learning, family, government, religion and so on, ${ }^{32}$ still others compare its precepts with Western philosophies. ${ }^{33}$

In this collection, Connolly relates his discussion of the Analects to supererogationism. "Supererogationism" is the view that there are actions that are morally good, but optional. The Confucian ethical tradition emphasizes unceasing progress toward the goal of sagehood, and so it is generally opposed to the idea of supererogation, 
because this implies that we may be satisfied with attaining some sub-sagely level of morality. Tim Connolly shows in his article "Sagehood and Supererogation in the Analects" that the one possible exception to this anti-supererogationist stance, however, turns out to be Confucius himself, who, in the Analects, appears to downplay sagehood and instead focuses on the goal of junzi 君子. Is sagehood supererogatory? Connolly suggests that this is probably not the case, and explains that Confucius is not denying the possibility of attaining sagehood but is asking people to focus on returning to the root and starting from what is more practical, rather than setting the bar too high, which would make moral cultivation a selfdefeating experience.

In striving for betterment and to become a junzi in the Confucian tradition, undoing negative reactive emotions against others such as resentment is a key element of becoming genuinely noble in the ethical sense. Eric Nelson investigates negative emotions in early Confucian sources through examples of resentment and related socially mediated feelings. In "Recognition and Resentment in the Confucian Analects," Nelson shows how early Confucian ethics integrates a complex, nuanced, and realistic moral psychology of the reactive sentiments within a normatively oriented project of self-cultivation. The Confucian ethical model requires dismantling complex negative emotions in order to promote a comportment of humane benevolence that is oriented toward others while being realized in the care for and cultivation of the self.

\section{The Four BOoKS}

For over two millennia the Confucian Classics have been the subject of persistent commentarial pursuit; so much so that paradigmatic Confucianism has built its transcendent truths around the Four Books. Detached from their historical contexts, Confucius's teachings are often regarded as a timeless homily on moral principles. The Four Books have been studied mainly through scriptural hermeneutics by which the meanings of words, phrases, and sentences have been well exploited and a schema of Confucian doctrines has been established. ${ }^{34}$ Conceptually, Chinese and Western hermeneutics both theorize that interpretation is not an ontic part of the text but is what the reader brings to the text. Western hermeneutic theories have been well developed while Chinese hermeneutics lags behind not in terms of qualitative inquiry but systematic presentation.

However, the gaps in the theorization of Chinese hermeneutics can be bridged by Western hermeneutics whose logical clarity can 
be applied to explain away the ellipses in the Chinese model. For example, Professor Chung-ying Cheng has in the past few decades engaged in what he termed ontological hermeneutics or ontogenerative hermeneutics in order to present, interpret, and reconstruct Chinese philosophy as a form of synthetic creativity in the Confucian Classics and the Yijing 《易經》. By employing a similar approach in "A Generative-Ontological Unity of Heart-Mind and Nature in the Four Books," Professor Cheng presents a thematic study of creativity and harmony in the Daxue and Zhongyong. Based on what he calls "onto-generative hermeneutics," he argues that both texts present a system of ethical and political philosophy, with the former focusing on the explicit use of the heart-mind for the creative development of a hidden nature as impelled by human emotions and to which the mind aspires, whereas the Zhongyong focuses on the participation of humankind in the creativity of heaven and earth based on the onto-generative nature (xing 性) of humanity. He further shows that from this analysis we can see how both the Daxue and Zhongyong address the dynamic relationship of nature and heartmind, each from a different perspective, and how these different perspectives are integrated from a holistic perspective of the source-body ontology (onto-generative metaphysics or simply generative ontology) of humanity.

Xinzhong Yao extends the discussion of the way of harmony as it is initiated in the Analects of Confucius and further elaborated in the other three of the Four Books. In "The Way of Harmony in the Four Books" he argues that Confucian harmony is a philosophy defining the relation between the self and the other, a notion which, among the elements of the unity, is a way of living and behaving that leads to modesty and flexibility; it is a moral process starting from the self and reaching the "middle way." He concludes that the way of harmony is not only theoretically important for Confucian philosophy but also practically significant for Chinese culture because it later became central to the doctrinal foundation on which all other Chinese philosophical schools were ideated.

We will see from the articles of this issue that there are many different ways to approach and analyze the Confucian Classics today just as it was the case in the last two thousand years. These canonical texts will continue to provide us with both opportunities and challenges to understand Chinese philosophy in their old and new contexts so long as we keep on our journey of discovering and rediscovering the words of wisdom from the ancient sages. 


\section{ENDNOTES}

I would like to express my gratitude to Professor Chung-ying Cheng and Dr. Linyu Gu for inviting me to organize this supplementary issue. I thank all authors for their contributions. I am grateful to Eric Nelson and Daniel Lee for their insightful comments from which I benefited greatly.

1. Huang Chun-chieh, "Contemporary Chinese Study of Confucian Hermeneutics," Dao: A Journal of Comparative Philosophy 4, no. 2 (2005): 353-70.

2. Richard E. Palmer, Hermeneutics (Evanston: Northwestern University Press, 1969), 13-15. It ought to be mentioned that hermeneutics has further developed into a branch of philosophy contemplating the ontology of "Being," time, thinking, language, history, and human experience, and so forth, as a hermeneutical conception, but discussions in this respect are outside the scope of this article.

3. Ibid., 76 .

4. Michael LaFargue, Tao and Method:A Reasoned Approach to Tao Te Ching (Albany: State University of New York Press, 1994), 6-7.

5. Palmer, Hermeneutics, 186.

6. William Blattner, Heidegger's Being and Time (London: Continuum, 2006), 4.

7. Palmer, Hermeneutics, 176.

8. Ibid., 174.

9. Ibid., 186.

10. LaFargue, Tao and Method, 7.

11. Steven Van Zoeren, Poetry and Personality (Stanford: Stanford University Press, 1991), 3-4.

12. To name a few of such works, see Li Qingliang 李清良, Zhongguo Chanshi Xue 《中國闡釋學》 (Hunan: Hunan Normal University Press, 2001); Huang Junjie (Chun-chieh) 黃俊傑, “Mengzi Yuyong Jingdian de Mailuo ji qi Jiejing Fangfa" “孟子運用經典的脈絡及其解經方法” (Mencius Hermeneutics of the Classic) as found in Li Minghui 李明輝's edited volumn Rujia Jingdian Quanshi Fangfa 《儒家經典詮釋方法》(Hermeneutics in Confucian Classics) (Taipei: National Taiwan University Press, 2008).

13. Mencius 5.A.4, translated by D. C. Lau (Hong Kong: The Chinese University Press, 2003), 200-1.

14. Huang Junjie, "Mengzi Yuyong Jingdian de Mailuo ji qi Jiejing Fangfa" as found in Li Minghui's edited volumn Rujia Jingdian Quanshi Fangfa (Taipei: National Taiwan University Press, 2008), 165-81.

15. Ibid., 173.

16. Ibid., 173.

17. Mencius, 5B:8, translated by D.C. Lau (Hong Kong: The Chinese University Press, 2003), 236-7.

18. Palmer, Hermeneutics, 185.

19. W. K. Wimsatt Jr., The Verbal Icon: Studies in the Meaning of Poetry (London: Methuen, 1970), 3.

20. Catherine Belsey, Critical Practice (London: Methuen, 1980), 3.

21. Wang Fuzhi, Chuanshan Yishu 《船山遺書》(Jinling: Xiangxiang Zengshi, 1866), 1-2. The original text reads: “作者用一致之思, 讀者各以其情而自得。” (Zuozhe yong yizhi zhi si, duzhe ge yi qi qing er zide).

22. James Legge, Life and Works of Mencius (London: Trübner, 1875), 279.

23. Louis Montrose, "Professing the Renaissance: The Poetic and Politics of Culture," in Literary Theory: An Anthology, eds. Julie Rivkin and Michael Ryan (Malden: Blackwell, 2004), 584.

24. Analects 7:1. The Master said, "I transmit but do not innovate...." See D. C. Lau, trans., Confucius The Analects (Hong Kong: The Chinese University Press, 2000), 57. In citing Lau's works, proper names as transliterated by Lau will be retained but pinyin will be provided in square brackets.

25. Shirley Chan, The Confucian Shi, Official Service, and the Confucian Analects (New York: Edwin Mellen, 2004), 221-7. 
26. Ibid., 3 .

27. Shu-hsien Liu, "A Philosophic Analysis of the Confucian Approach to Ethics," Philosophy East and West 22, no. 4 (1972): 417-25.

28. Chan, The Confucian Shi, 10.

29. Examples of these works include Luo Zuji, ed., Kongzi sixiang yanjiu lunji 《孔子思想研究論集》 (A Collection of Essays on Confucian Teaching) (Jinan: Qilu Press, 1987); Wang Ziyuan, Lunyu xinbian 《論語新編》 (Heilongjian: Xinhua Book Shop, 1991); Li Zhenhong, Shengren zhenyanlu: Lunyu yu Zhongguo wenhua 《聖人筬言錄：論語與中國文化》 (The Words of the Sage: The Analect and Chinese Culture) (Kaifeng: Henandaxue Press, 1995).

30. Roger T. Ames and Henry Rosemont Jr., The Analects of Confucius: A Philosophical Translation (New York: Ballantine, 1984).

31. See works by Herbert Fingarette, Confucius-The Secular as Sacred (New York: Harper \& Row, 1972).

32. Benjamin I. Schwartz, "The Intellectual History of China: Preliminary Reflections," in Chinese Thought and Institutions, ed. John K. Fairbank (Chicago: University of Chicago Press, 1957), 15-30.

33. David L. Hall and Roger T. Ames, Thinking through Confucius (Albany: State University of New York Press, 1987).

34. Chan, The Confucian Shi,2-3. 